\title{
The need for a cultural shift from two-arm to multi-arm RCTS
}

\author{
Matthew R Sydes ${ }^{1,2^{*}}$, Mahesh KB Parmar ${ }^{1,2}$ \\ From 2nd Clinical Trials Methodology Conference: Methodology Matters \\ Edinburgh, UK. 18-19 November 2013
}

\section{Proposal}

We need a faster and more efficient way of improving patient outcomes in all disease areas. There is a need for a cultural shift in randomised phase III superiority trials. We propose there be fewer two-arm trials and more trials that incorporate multiple research arms.

\section{Setting}

Well-designed, well-conducted randomised controlled trials (RCTs) are the most reliable way to collect comparative evidence on efficacy and effectiveness, and drive changes in policy and healthcare. A literature search has shown that $\sim 80 \%$ of all trials have only 2 arms. A key problem is their low success rate, defined as a convincing finding that the research treatment is better than the current standard-of-care. New treatments commonly do not work as well as hoped, yet we persist with traditional phase III RCTs, that are both expensive and often take many years. A direct conclusion from the high failure rate is that the information on which phase III trials are designed must be flawed. In planning any 2 -arm phase III trial, fundamental uncertainties often remain; for example, whether we have reliably selected the most appropriate dose and/or duration of treatment or, for the academic community, whether other treatments have equal (or greater) priority for being assessed?

\section{Conclusion}

An academic RCT should not be seen as a way of assessing a specific treatment, but considered as a central tool to improving outcomes for patients with a particular condition as quickly as possible. Therefore, we argue that many more trials should have more than one research arm.

${ }^{1}$ MRC Clinical Trials Unit, London, UK

Full list of author information is available at the end of the article
Authors' details

${ }^{1}$ MRC Clinical Trials Unit, London, UK. ${ }^{2}$ MRC Clinical Trials Unit Hub for Trials Methodology Research, London, UK.

Published: 29 November 2013

doi:10.1186/1745-6215-14-S1-O3

Cite this article as: Sydes and Parmar: The need for a cultural shift from two-arm to multi-arm RCTS. Trials 2013 14(Suppl 1):O3.
Submit your next manuscript to BioMed Central and take full advantage of:

- Convenient online submission

- Thorough peer review

- No space constraints or color figure charges

- Immediate publication on acceptance

- Inclusion in PubMed, CAS, Scopus and Google Scholar

- Research which is freely available for redistribution
C Biomed Central 